DOI: $10.6060 / \mathrm{mhc} 150145 \mathrm{~b}$

\title{
Study of Monomeric and Dimeric Chlorophyll $a$ Derivatives by Diffusion Ordered Spectroscopy (DOSY) Method
}

\author{
A. L. Stolypko, ${ }^{\mathrm{a}, \mathrm{b}}$ D. V. Belykh, ${ }^{\mathrm{a} @}$ and O. M. Startseva ${ }^{\mathrm{a}}$ \\ anstitute of Chemistry, Komi Scientific Center, Ural Division of Russian Academy of Sciences, 167982 Syktyvkar, Russia \\ ${ }^{\mathrm{b}}$ Syktyvkar State University, 167000 Syktyvkar, Russia \\ ${ }^{\circledR}$ Corresponding authorE-mail: belykh-dv@mail.ru
}

\begin{abstract}
Monomeric and dimeric chlorophyll a derivatives were studied by diffusion ordered spectroscopy (DOSY) method. It has been shown that DOSY method allows to detect a change of molecular dimensions corresponding to the transition from monomeric to dimeric porphyrin. However, the variation value of these changes depends on the nature of substituents at the macrocycle periphery. So when estimating the molecular weight of studied derivative it is necessary to compare the diffusion characteristics with compounds of known masses and similar substituents system in the macrocycle.
\end{abstract}

Keywords: Chlorophyll $a$, dimerization, diffusion ordered spectroscopy (DOSY).

\section{Исследование мономерных и димерных производных хлорофилла $a$ методом DOSY}

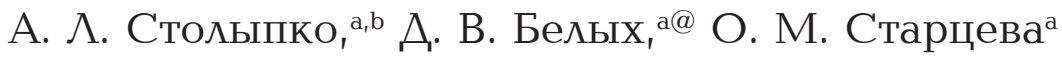 \\ ${ }^{\mathrm{a}}$ Институт химии Коми научного изентра Уральского отделения РАН, 167982 Сыктывкар, Российская Федерация \\ ${ }^{\mathrm{b}}$ Сыктывкарский государственный университет, 167000 Сыктывкар, Российская Федерация \\ ${ }^{\circledR}$ E-mail: belykh-dv@mail.ru
}

\begin{abstract}
Исследованы мономерные и димерные производные хлорофилла а методом DOSY. Установлено, что метод DOSY позволяет зафиксировать изменение размеров молекул, соответствующее переходу от мономерного порфирина к димерному. Однако величина этих изменений существенно зависит от природы периферических заместителей в макроцикле, поэтому при оценке молекулярной массы исследуемого производного необходимо сравнивать его диффузионные характеристики с соединениями известной массы со сходной системой заместителей в макрочикле.
\end{abstract}

Ключевые слова: Хлорофилл $a$, димеризация. метод DOSY.

It is known that multi porphyrin molecules are of interest as model compounds, the molecular receptors and biological active substances. ${ }^{[1-5]}$ An important aspect of evidence of such derivatives structure is determining of their molecular weight, which is usually carried out by means of different variants of mass spectrometry. However in many cases the intensity of the molecular ion in the mass spectra of such derivatives is relatively small and fragmentary ions of lower mass are observed. Therefore even rough estimation of molecular weight of such derivatives by independent method would be useful.
Since the molecular size of the monomeric and dimeric derivatives should differ from each other significantly the comparison of diffusion characteristics of these compounds can be used to prove the presence of two macrocycles in the molecules. These data can be obtained using the twodimensional diffusion ordered spectroscopy (DOSY) experiments. ${ }^{[6]}$ However the data on this method for the porphyrin compounds are absent in the literature. Here we have studied the monomeric and dimeric chlorophyll $a$ derivatives (1-8) to determine the DOSY capacities in the estimation of molecular weights of these compounds. 


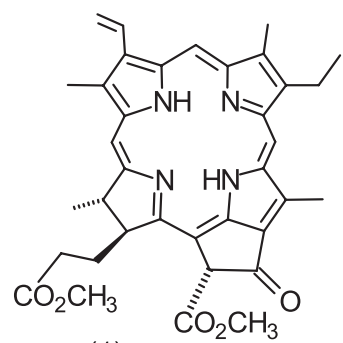

(1)

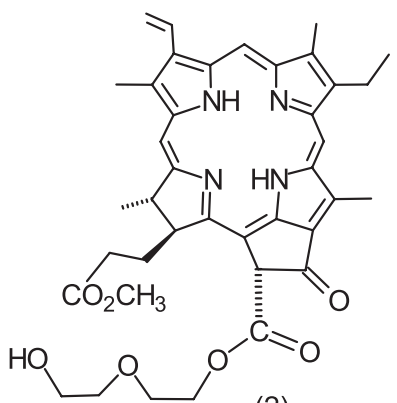

(2)

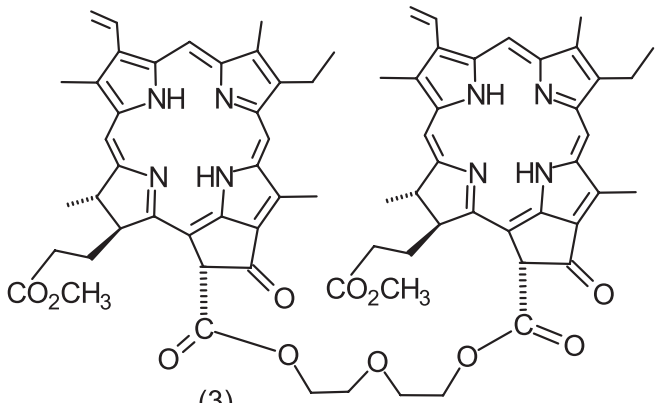

(3)

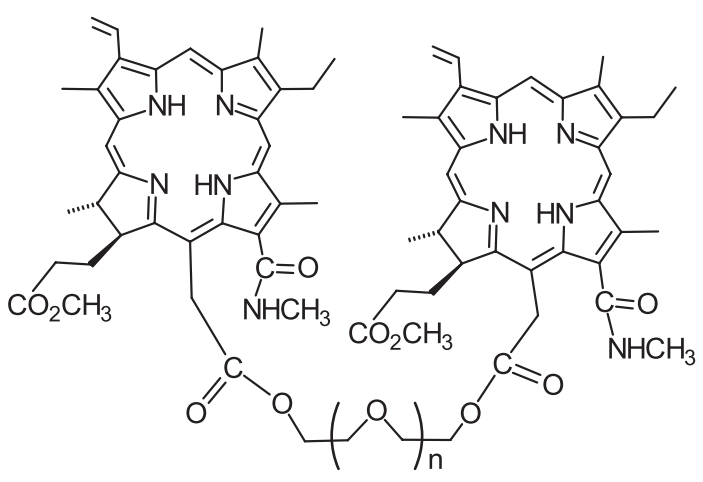

(4): $n=3 ;(5): n=1$

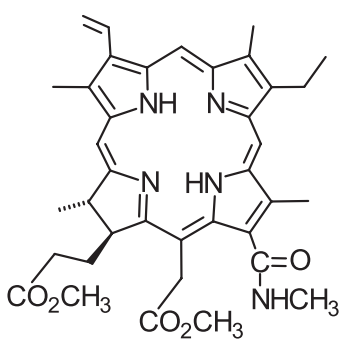

(6)

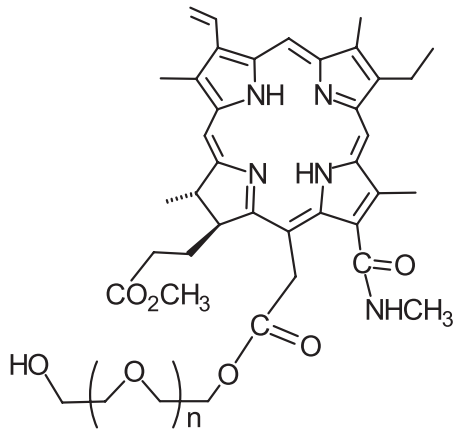

(7): $n=1 ;(8): n=3$

Scheme 1.

Chlorophyll derivatives were synthesized according to ${ }^{[7]}$. The measurements were carried out by Bruker Avance II spectrometer $(300 \mathrm{MHz})$ for solutions in DMSO- $d_{6}$. The experiment parameters: D 20 $=0.1 \mathrm{~s} ; \mathrm{P} 30=1600 \mu \mathrm{s} ; \mathrm{NS}=16$; td $(\mathrm{F} 1)=32$. The experiment was carried out at stabilized temperature $\left(24{ }^{\circ} \mathrm{C}\right)$ and using an air cushion to decrease induced vibration.

Table 1 The diffusion coefficients of monomeric and dimeric chlorophyll $a$ derivatives (1-8).

\begin{tabular}{ccc}
\hline $\begin{array}{c}\text { The } \\
\text { compound } \\
\text { number }\end{array}$ & $\begin{array}{c}\mathrm{M}_{\mathrm{r}} \text { of porphyrin } \\
(\mathrm{mol} \% \text { of porphyrin })\end{array}$ & $\begin{array}{c}\text { The diffusion } \\
\text { coefficient, } \\
\left(\times 10^{10}\right) \mathrm{m}^{2} / \mathrm{sec}\end{array}$ \\
\hline \multicolumn{3}{c}{ A series of measurements 1 } \\
$\mathbf{1}$ & $606.72\left(6.46 \cdot 10^{-5}\right)$ & 3.28 \\
$\mathbf{2}$ & $680.80\left(6.11 \cdot 10^{-5}\right)$ & 3.28 \\
$\mathbf{3}$ & $1255.48\left(6.34 \cdot 10^{-5}\right)$ & 2.80 \\
& A series of measurements 2 \\
$\mathbf{4}$ & $1405.70\left(5.75 \cdot 10^{-5}\right)$ & 1.92 \\
$\mathbf{6}$ & $637.78\left(7.68 \cdot 10^{-5}\right)$ & 2.69 \\
$\mathbf{8}$ & $799.96\left(6.12 \cdot 10^{-5}\right)$ & 2.31 \\
& A series of measurements 3 & \\
$\mathbf{5}$ & $1317.60\left(7.43 \cdot 10^{-5}\right)$ & 2.15 \\
$\mathbf{6}$ & $637.78\left(7.68 \cdot 10^{-5}\right)$ & 2.69 \\
$\mathbf{7}$ & $711.86\left(6.36 \cdot 10^{-5}\right)$ & 2.60 \\
\hline
\end{tabular}

The monomeric $(\mathbf{1}, \mathbf{2}, \mathbf{6 - 8})$ and dimeric (3-5) chlorophyll $a$ derivatives (Scheme 1), the effective size of which in solution should be significantly different from each other, were selected for molecular weight estimation. Dimeric derivatives $\mathbf{4}$ and $\mathbf{5}$ with different length of spacers were also investigated. It is known that the aggregation of porphyrin molecules is possible in solution and this process can affect on the diffusion characteristics measurements results. Therefore, deuterated dimethylsulfoxide (DMSO- $d_{6}$ ) was selected as a solvent. DMSO is a highly solvating solvent, what helps to prevent aggregation processes and to minimize the possible effects of aggregation. The effective volumes of molecules are inversely proportional to molecular diffusion coefficients of the third degree, ${ }^{[6]}$ therefore, the changing of effective volume of the molecules during the transition from monomer to dimer can be calculated from the values obtained. It has been shown that the effective volumes of diffusing particles increase in monomer-dimer pairs with the same type of substituents in the macrocycle when moving from monomeric to dimeric molecules (pairs 1-3, 2-3, 6-5, 7-5, 4-6, 4-8). However, changes in the effective volumes are different for different types of macrocycle substituents. On going from monomeric compounds $\mathbf{1}$ and $\mathbf{2}$ to the dimer 3 the increasing of effective volume is of 1.6 times, and on going from monomer $\mathbf{6}$ to the dimer 5 the increasing of effective volume is of 2.7 times. For the pair of monomer 7 and dimer 4 the effective volume is increased by 1.8 times, which is clearly associated with the presence of diethylene glycol moiety in the molecule $\mathbf{7}$. In the case of dimer $\mathbf{4}$, the situation is similar. The effective volume of particles formed by dimer 4 is of 3.8 times greater than that of the particles formed by the monomer $\mathbf{6}$ and only 1.7 times greater than that of the particles formed by monomer $\mathbf{8}$, the molecule of which has a tetraethylene glycol fragment. Various changes in the effective volumes at transition from monomeric to dimeric derivatives and the dependence on the nature of substituents in the macrocycle can be explained by possibility of differences 
in average angle between macrocycles in dimeric molecules and that affects on the defined effective volume.

Thus, the method of diffusion ordered spectroscopy (DOSY) allows to detect the changing of molecular dimensions corresponding to the transition from monomeric to dimeric porphyrin. However, the variation value of these changes depends on the nature of substituents at the macrocycle periphery. So when estimating the molecular weight of studied derivative it is necessary to compare the diffusion characteristics with compounds of the known masses and similar substituents system in the macrocycle.

\section{References}

1. Chlorophylls and Bacteriochlorophylls. Biochemistry, Biophysics, Functions and Applications (Grimm B., Porra R.J.,
Rüdiger W., Scheer H., Eds.). Series “Advances in Photosynthesis and Respiration", Vol. 25, Springer, 2006. 603 p.

2. Koifman O.I., Mamardashvili N.Zh., Antipin I.S. Synthetic Receptors on the Basis of Porphyrins and Their Conjugates with Calix[4]arenes, Moscow: Nauka, 2006. 246 p. (in Russ.) [Койфман О.И., Мамардашвили Н.Ж., Антипин И.С. Синтетические реиепторы на основе порфиринов и их конъюгатов с каликс[4]аренами, М.: Наука, 2006. 246 с.]

3. Nyman E.S., Hynninen P.H. J. Photochem. Photobiol. B: Biology 2004, 73, 1-28.

4. Wojaczynski J., Latos-Grazynski L. Coord. Chem. Rev. 2000, 204, 113-171.

5. Sternberg E.D., Dolphin D. Tetrahedron 1998, 54, 41514202.

6. Heisel K.A., Goto J.J., Krishnan V.V. Am. J. Anal. Chem. 2012, 3, 401-409.

7. Startseva O.M., Belykh D.V., Shegera V.M., Tulaeva L.A. Butlerov Communications 2014, 38(6), 43-48 (in Russ.). 